\title{
Antidiabetic Activity of Sungkai (Peronema canescens Jack) Leaves Ethanol Extract on the Male Mice Induced Alloxan Monohydrate
}

\author{
Madyawati Latief ${ }^{1}$, Putri M. Sari², Liddini T. Fatwa², Indra L. Tarigan ${ }^{1}$, H. P. Vasantha Rupasinghe ${ }^{3}$ \\ ${ }^{1}$ Program Study of Chemistry, Faculty of Science and Technology, \\ Universitas Jambi, Jambi - Indonesia \\ ${ }^{2}$ Department of Pharmacy, Faculty of Medicine and Health Sciences, \\ Universitas Jambi, Jambi - Indonesia \\ ${ }^{3}$ Department of Plant, Food, and Environmental Sciences, Faculty of Agriculture, \\ Dalhousie University, Truro, Nova Scotia - Canada
}

\begin{abstract}
Sungkai (Peronema canescens Jack) is an alternative natural ingredient that can be used as an antidiabetic containing several secondary metabolites which are thought to reduce blood glucose levels by inhibiting the action of the $\alpha$-glucokinase enzyme and increasing the activity of antioxidant enzymes and being able to regenerate $\beta$-cells, damaged pancreas so that insulin deficiency can be overcome. The aim of this study was to determine the effect of $P$. canescens leaves ethanol extract on antidiabetic activity and to determine the effect of various doses of sungkai leaf ethanol extract as antidiabetic. The scientific research method used in this study was a completely randomized design (CRD) and data analysis used in this study is the one way ANOVA, following by the Duncan test. Blood glucose measurement in treated mice was carried out 3 times. Mice were devided into five groups, three mice in each group, and each group was administered different dosages of sungkai extract $(\mathrm{T} 1=$ extract $175 \mathrm{mg} / \mathrm{kg}$ body weight; T2 = extract $350 \mathrm{mg} / \mathrm{kg}$ body weight; T3 = extract $700 \mathrm{mg} /$ $\mathrm{kg}$ body weight). First, the mice were acclimatized for six days and the injection of treatment was started at day 7. Blood glucose levels, urine volume, body weight and daily drinking of mice was carried out before induction (day 0), after induction (day 8) and after the end of treatment for 10 days (day 18), was carried out using the Point of Care Test (POCT) method using the Easy Touch GCU. The results showed that the ethanol extract of sungkai leaves had the potential to reduce blood glucose levels in mice. The ethanol extract of sungkai leaves at a dose of $350 \mathrm{mg} / \mathrm{kg}$ body weight has the most optimal potential to reduce blood glucose levels, urine volume, daily drinking, and body weight.
\end{abstract}

Keywords: Sungkai (Peronema canescens Jack), Ethanol Extract, Antidiabetic Activity

Corresponding author: Madyawati Latief. Department of Chemistry, Faculty of Science and Technology, Universitas Jambi, Jambi - Indonesia. Email: madyawatilatief@unja.ac.id

Received: 12 January 2021. Revised: 13 April 2021 . Published: 8 August 2021 


\section{Introduction}

Diabetes mellitus (DM) known as a chronic metabolic disease caused by insulin deficiency or insulin resistance. ${ }^{1}$ Most prominent factors such as dyslipidemia, hyperglycemia, insulin resistance, impaired secretion, and proinflammatory mediators activation contribute to the rapid incidence and advancement of DM. More than 90\% of all diabetic population belongs to Type-2 diabetes mellitus (T2DM). Somehow, DM is following by renal failure, coronary artery disease, blurred vision, neuropathy, and impaired wound healing that may predispose limb amputation. ${ }^{2,3}$

In contrast to type $1, \mathrm{DM}$ is a disease in which the immune system attacks the $\beta$-cells which function to produce the hormone insuline. In fact, T2DM affects more than 200 million people worldwide by expected to reach 642 million by 2024 based on a report presented by the International Diabetes Federation (IDF) in $2015 .^{4,5}$ In Indonesia, diabetes accounts for $3 \%$ of the total $63 \%$ of deaths due to noncommunicable diseases. Its estimate that in 2025 there will be an increase in the number of people with DM from 5 million in 1995 to 12 million people with DM in the world. ${ }^{6,7}$

Generally, in DM case, the body is not able to produce insulin due to the $\beta$-cells of the islets of Langerhans experience inflammation. Clinically, there are several antidiabetic drugs can reduce blood glucose levels by stimulating the $\beta$-cells of Langerhans islands to produce insulin. ${ }^{8}$ However, insulin therapy, oral antidiabetics (ADO), or the use of both usually last a long time and cause unwanted side effects, and experiencing many obstacles, especially in terms of patient compliance and high costs..$^{9,10}$

There is an alternative DM drug candidate to minimize side effects by utilizing medicinal plants, including the Sungkai plant (Peronema canescens Jack). The Dayak tribe in East Kalimantan used it for treatment or health care. Peronema canescens (P. canescens), the Verbenaceae tribe on the leaves used as cold medicine, fever, ringworms medicine, and a water bath. Somehow, it also uses for women after childbirth and as a mouthwash to prevent toothache. ${ }^{11,12}$

Previous studies were reported that $P$. canescens) contain several bioactive compound, and the bioactive compound might act as antimalarial, antiplasmodial, ${ }^{13}$ antibacterial, ${ }^{14}$ analgesic, and immunomodulator. ${ }^{15} P$. canescens leaves contains bioactive compound such as flavonoids, alkaloids, steroids, tannins, phenol, and saponins. ${ }^{14}$ Previous studies showed that flavonoids have antioxidants activity which supposed to protect the body against damage caused by ROS (Reactive Oxygen Species) in preventing DM..$^{8,14,16}$

Flavonoids play a significant role in increasing the activity of antioxidant enzymes, regenerate damaged $\beta$-cells of the pancreas, and improve the sensitivity of insulin receptors. ${ }^{17}$ Besides, the tannin content act as antibacterial, ${ }^{18}$ inhibit glucose absorption in the intestine, inhibit adipogenesis, act as anti-free radicals and activate antioxidant enzymes that regenerate pancreatic $\beta$ cells. ${ }^{19}$ Likewise, saponins are able to reduce glucose absorption in the intestine by damaging the arrangement of cell membranes. ${ }^{20,21}$ Unfortunately, the research on $P$. canescens is still minimal, so it becomes an opportunity for deeper scientific exploration.

\section{Methods}

Materials and Tools

$P$. canescens Jack were collected from Senaung Village, Jambi Luar Kota District, Muaro Jambi Regency, Jambi Province. The 
chemicals used were alloxan monohydrate, $70 \%$ ethanol, Glibenclamide $\AA$, $0.5 \% \mathrm{Na}-$ CMC, Aquadest, $0.9 \% \mathrm{NaCl}, 50 \%$ sucrose. The animal used in this study were 45 wistar male mice, lines weighing 20-30 g, aged 2-3 months, and in a healthy and normal condition. Before the testing, the experimental animals have acclimated alloxan for one week.

\section{Sungkai Leaves Extraction (Peronema canescens Jack) \\ P. canescens Jack (family: Lamiaceae) leaves were obtained from Senaung Village, Jambi Luar Kota District, Muaro Jambi Regency, Jambi. Determination was carried out at the Biotechnology and Engineering Laboratory, Faculty of Science and Technology, Jambi University.}

The leaves of $7.6 \mathrm{~kg}$ sungkai were sorted, cleaned, chopped and dried to produce $2.5 \mathrm{~kg}$ of simplicia. Drying was carried out at room temperature for 7 days. The yield value of simplicia was obtain $32.89 \%$. $1.5 \mathrm{~kg}$ of the powder simplicia was macerated using $70 \%$ ethanol to attract relatively polar compounds such as phenols, flavonoids, saponins, and other polar compounds contained in sungkai leaves. The maserate filtrate was produced using a Buechner funnel and evaporated using a rotary evaporator. ${ }^{25}$

\section{Research Procedures}

The mice used were acclimatized for 7 days to adapt to the environment of the test site. The experimental design was a completely randomized design (CRD) of test animals used as many as 45 animals with five treatments (Table 1), each treatments consisting of 3 wistar male mice with three repetitions.

\section{Ethanol leaves extract of P. canescens Jack}

The leaves were first thoroughly washed with distilled water and allowed to dry under shade with optimal ventilation at $40-450^{\circ \mathrm{C}}$, then chopped to coarse powder. Eight hundred gram of coarse powdered of P. canescens was macerated in $70 \%$ ethanol solvent for 72 hours. The extract was made by inserting one part of the dry powder into a dark-colored glass bottle, then adding 10 parts of the solvent. Then soaked for the first 6 hours, stirring occasionally, then let stand for 18 hours. The macerate then separated by filtration using a Buechner funnel to speed up the filtering. The macerate was collected and evaporated with a vacuum or lowpressure evaporator until a thick extract was obtained. Then, calculated the yield obtained, the percentage of weight $(\mathrm{w} / \mathrm{w})$ between the yield, and the weight of the simplicia powder.

\section{Specific and Non-Specific Parameters}

Analysis of non-specific parameters was carried out by measuring the ash content, moisture content, and drying shrinkage. Meanwhile, the specific parameters analyzed were smell, shape, color and taste.

\section{Secondary Metabolite Screening}

Examination of the extract phytochemical compounds was carried out by referring to previous research. The secondary metabolites to be analyzed were alkaloids, steroids, terpenoids, flavonoids, saponins, tannins, and phenolics.

\section{Antidiabetic Activity}

The dosage of sungkai leaves extract to be used refers to previous study $175 \mathrm{mg} / \mathrm{kg}$ body weight, $350 \mathrm{mg} / \mathrm{kg}$ body weight and $700 \mathrm{mg} / \mathrm{kg}$ body weight. The alloxan dose to be used to induce alloxan in this study refers to previous study $150 \mathrm{mg} / \mathrm{kg}$ body weight, while the dose of glibenclamide to be used was $3 \mathrm{mg} / \mathrm{kg}$ body weight. ${ }^{8,22}$ (Table 1)

The antidiabetic activity was carried out by following previous research Sari (2010) measure the mice's initial blood sugar level 
Table 1. Antidiabetic Activity Test Treatment Group

\begin{tabular}{|c|c|}
\hline Samples Group & Treatment \\
\hline Negative Control (C-) & Alloxan $150 \mathrm{mg} / \mathrm{kg}$ bodyweight and $\mathrm{Na}-\mathrm{CMC} 0.5 \%$ \\
\hline Positive Control $(\mathrm{C}+)$ & $\begin{array}{l}\text { Alloxan dose of } 150 \mathrm{mg} / \mathrm{kg} \text { bodyweight and administration } \\
\text { of glibenclamide } 3 \mathrm{mg} / \mathrm{kg} \text { bodyweight }\end{array}$ \\
\hline Treatment 1 (T1) & $\begin{array}{l}\text { Alloxan dose of } 150 \mathrm{mg} / \mathrm{kg} \text { bodyweight and giving } 175 \mathrm{mg} / \\
\mathrm{kg} \text { bodyweight of sungkai leaves extract }\end{array}$ \\
\hline Treatment 2 (T2) & $\begin{array}{l}\text { Alloxan dose of } 150 \mathrm{mg} / \mathrm{kg} \text { bodyweight and administration } \\
\text { of sungkai leaves extract } 350 \mathrm{mg} / \mathrm{kg} \text { bodyweight }\end{array}$ \\
\hline Treatment 3 (T3) & $\begin{array}{l}\text { Alloxan dose of } 150 \mathrm{mg} / \mathrm{kg} \text { bodyweight and administration } \\
\text { of } 700 \mathrm{mg} / \mathrm{kg} \text { bodyweight of sungkai leaves extract }\end{array}$ \\
\hline
\end{tabular}

Table 2. Non-Specific Characters of Sungkai Leaves Extract

\begin{tabular}{cc}
\hline Parameter & Result (\%) \\
\hline Yield & 13.7 \\
Water Content & 6.2 \\
Ash Content & 6.8 \\
\hline
\end{tabular}

(day 1) before induction, then followed by mice induction with alloxan at a dose of $150 \mathrm{mg} / \mathrm{kg}$ body weight in all groups. Mice were fed and drank as usual, then observed the mice's condition on the sixth day after induction (day 7) and measured the blood sugar levels of the mice. Diabetic mice (blood sugar level $>176 \mathrm{mg} / \mathrm{dL}$ ) will be used in the trial.

Furthermore, the mice were given a test solution (extract and glibenclamide suspension) according to the group and the dose each day for ten days. On the day 10 after giving the test solution (day 18). Blood glucose levels were determined by taking blood from the veins located at the tail end of the mice and then measuring their levels with a glucometer. Each time the blood was drawn, the mice had to fast for 8-12 hours with continued drinking water.

\section{Statistical Analysis}

The qualitative content of secondary metabolites will be analyzed descriptively, blood sugar levels, body weight, urine volume and drinking water consumption will be analyzed using SPSS Version 21 . The analysis was carried out, namely the normality test and homogeneity test, then carried out one-way analysis of variations (One Way ANOVA), if there are differences between treatments, it will be continued with the Duncan test ( $p$-value). $(\mathrm{P}>0.05)$. Superscripts $\mathrm{A}, \mathrm{B}$, and $\mathrm{AB}$ showed significant differences between treatments. Treatment with the same superscript showed insignificant results, while different superscripts showed significantly different results

\section{Results and Discussion}

The extraction results obtained a thick extract of sungkai leaves as much as 206 grams with a yield value of $13.75 \% ; 6.2 \%$ of the water content and the moisture content was $5-30 \%$. (Table 2). The high-water content effects to physical and chemical properties of the extract and changing the chemical of the extract. In addition, the total ash content obtained was $6.8 \%$ which is in accordance with the 
Table 3. Phytochemical Results of Ethanol Extract of P. canescens Leaves

\begin{tabular}{cc}
\hline Secondary Metabolite & Result \\
\hline Phenol & + \\
Flavonoids & + \\
Tannins & + \\
Alkaloids & + \\
Steroids & - \\
Saponins & + \\
\hline
\end{tabular}

requirements for the extract ash content $<16.6 \%$. The high ash content indicates the high level of minerals contained in sungkai leaves. Also, if the ash content contained in the extract is high enough, it also indicated the presence of impurities such as soil, sand, or other impurities which can also affect the quality of the extract obtained.

The results of phytochemical screening showed that the ethanol extract of Sungkai leaves contains secondary metabolites of phenols, flavonoids, tannins, sapponins, and alkaloids (Table 3). ${ }^{23,24}$

Flavonoids and saponins can play a significant role in increasing the activity of antioxidant enzymes and are able to regenerate damaged $\beta$ cells of the pancreas, thereby inhibiting insulin deficiency. The $\alpha$-glucosidase enzyme is an enzyme that plays a role in converting carbohydrates into glucose. By inhibiting the $\alpha$-glucosidase enzyme, the glucose (sugar) level in the blood will decrease, causing a hypoglycemic effect (decreased blood sugar levels). ${ }^{26}$

Saponins are able to regenerate the pancreas which causes an increase in the number of pancreatic $\beta$ cells. Increased insulin secretion will help reduce blood glucose levels. Tannin compounds are known to act as astringents that can precipitate intestinal mucous membrane proteins and form a layer that protects the intestines, thereby inhibiting glucose absorption as an antidiabetic activity, so that sungkai leaf extract containing these compounds also has potential as an antidiabetic. $^{20}$

Secondary metabolite compounds in $P$. canescens leaves extract are thought to be able to reduce blood sugar levels of diabetic mice, thus, the measurements of mice blood sugar levels were taken on three different time. The DM condition was conducted by induction of alloxan in the peritoneum that may cause selective damage to pancreatic $\beta$ cells, reduce the amount of insulin secretion and the body cannot use glucose as an energy source. ${ }^{26}$

As a positive control, the synthetic drug Glibenclamide ${ }^{\circledR}$ was used and a negative control with $0.5 \%$ Na-CMC carrier suspension which was neutral and did not affect blood glucose levels. Antidiabetic activity parameters that will be measured include blood sugar levels, body weight, urine volume, and daily drinking water consumption. ${ }^{27}$ Observation of blood glucose levels of mice was carried out before induction (day 0), after induction (day 8) and after the end of treatment for 10 days (day 18). Data from the analysis of blood glucose levels in test animals is presented in Table 4.

The results showed that blood sugar levels on day 0 were not significantly different among the treated groups. This means that the 
Table 4. Alloxan-induced Blood Glucose Levels

\begin{tabular}{ccccc}
\hline \multirow{2}{*}{$\begin{array}{c}\text { Treatment } \\
\text { Group }\end{array}$} & \multicolumn{2}{c}{ The Average of Blood Glucose Levels ( mg/dL) \pm SEM } & $\begin{array}{c}\text { Increased Blood } \\
\text { Days }\end{array}$ & $\begin{array}{c}\text { Sugar Levels } \\
\text { (\%) }\end{array}$ \\
\cline { 2 - 4 } & Day 0 & Day 8 & Day 18 & +21.47 \\
\hline $\mathrm{C}-$ & $123.5^{\mathrm{B}} \pm 8.8$ & $247.3^{\mathrm{AB}} \pm 17.3$ & $300.4^{\mathrm{B}} \pm 16.78$ & -69.07 \\
$\mathrm{~T} 1$ & $122.3^{\mathrm{AB}} \pm 5.1$ & $217.0^{\mathrm{A}} \pm 13.3$ & $67.1^{\mathrm{A}} \pm 5.9$ & -71.98 \\
$\mathrm{~T} 2$ & $103.7^{\mathrm{AB}} \pm 5.40$ & $278.8^{\mathrm{AB}} \pm 28.4$ & $78.1^{\mathrm{A}} \pm 12.1$ & -69.81 \\
$\mathrm{~T} 3$ & $109.7^{\mathrm{A}} \pm 3.4$ & $227.3^{\mathrm{AB}} \pm 11.1$ & $68.6^{\mathrm{A}} \pm 12.24$ & -72.69 \\
$\mathrm{C}+$ & $139.1^{\mathrm{AB}} \pm 4.84$ & $282.7^{\mathrm{A}} \pm 23.8$ & $77.7^{\mathrm{A}} \pm 10.67$ & \\
\hline
\end{tabular}

A,BSuperscripts with different capital letters in the same column indicate very significant differences $(\mathrm{P}<0,05)$.

$\mathrm{C}-=0 \mathrm{mg}$ fraction $/ \mathrm{kg}$ bodyweight; $\mathrm{C}+=$ Glibenclamide $3 \mathrm{mg} / \mathrm{kg}$ bodyweight; $\mathrm{T} 1=$ extract $175 \mathrm{mg} / \mathrm{kg}$ bodyweight; T2 = extract $350 \mathrm{mg} / \mathrm{kg}$ bodyweight; T3 = extract $700 \mathrm{mg} / \mathrm{kg}$ bodyweight; SEM= Standar Error of Mean.

treated animals used in the same condition have normal blood sugar levels. Normal blood sugar levels in mice are in the range 62.8-176.0 $\mathrm{mg} / \mathrm{dL}$. On day 8, blood sugar levels was also found not significant different among the treated groups, indicated that the treated animals suffer from hyperglycemia (blood sugar levels> $176 \mathrm{mg} / \mathrm{dL}$ ). Moreover, on day 18 (after the administration of sungkai leaf extract) there were significant difference between the $\mathrm{C}+, \mathrm{T} 1, \mathrm{~T} 2$, and $\mathrm{T} 3$ treatment groups and the $\mathrm{C}$ - treatment group. This showed that the administration of sungkai leaf extract can cause a decrease in blood glucose in mice in the group given the extract.

Furthermore, the results of the t-test showed a significant difference $(\mathrm{P}<0.05)$ between day 8 and day 18 , which means that the provision of sungkai leaves caused a decrease in blood glucose in mice, but in group $\mathrm{C}$ - the increase was due to not given sungkai leaves extract.

Hyperglycemia that occurs in alloxan-induced mice is due to reduced insulin secretion as a result of damage to pancreatic $\beta$ cells. In in vitro study, alloxan causes necrosis of pancreatic $\beta$-cells by stimulating intracellular $\mathrm{H}_{2} \mathrm{O}_{2}$. Alloxan also disrupts the homeostasis of cells, this is the beginning of cell death due to disruption of the cell oxidation process.
The increased concentration of calcium ions accelerates the damage to pancreatic $\beta$-cells. When the $\beta$-cells of the pancreas are damaged by alloxan, there is a disruption in insulin secretion resulting in a reduced amount of insulin secretion. Decreased insulin secretion results in the body unable to use glucose as an energy source.

Alloxan induction that fails in mice can be induced with sucrose with a concentration of $50 \%$, this is because sucrose can increase the content of free fatty acids in plasma and induce insulin resistance resulting in T2DM similar to humans. ${ }^{28}$ Where an increase in sucrose concentration has an effect on increasing total sugar, the higher the sucrose is added, the higher the total sugar will be. ${ }^{29}$

After 10 days of treatment (day 18), the average of blood sugar levels of mice in all treatment groups were significantly lower than the negative control group. Meanwhile, blood sugar levels at T3 were significantly lower than T1, but not significantly different from $\mathrm{T} 2$ and $\mathrm{C}+$. The blood sugar levels of mice after giving the extract decreased significantly compared to C- (negative control)(Table4). The ability of P. cannescens leaf extract to reduce blood sugar levels in mice is also influenced by the number of 
Table 5.The Average Body Weight Before and After Treatment

\begin{tabular}{cccc}
\hline \multirow{2}{*}{$\begin{array}{c}\text { Treatment } \\
\text { Group }\end{array}$} & \multicolumn{2}{c}{ The Average of Blood Glucose Levels ( mg/dL) \pm SEM } \\
\cline { 2 - 4 } Days & Day 8 & Day 18 \\
\hline C- & $23.4^{\mathrm{A}} \pm 0.76$ & $24.6^{\mathrm{A}} \pm 0.52$ & $21.8^{\mathrm{A}} \pm 0.35$ \\
$\mathrm{~T} 1$ & $23.1^{\mathrm{A}} \pm 1.04$ & $24.7^{\mathrm{A}} \pm 0.32$ & $28.7^{\mathrm{B}} \pm 0.46$ \\
T2 & $23.0^{\mathrm{A}} \pm 0.94$ & $25.2^{\mathrm{A}} \pm 0.72$ & $28.0^{\mathrm{B}} \pm 0.57$ \\
T3 & $24.4^{\mathrm{A}} \pm 0.66$ & $26.2^{\mathrm{A}} \pm 0.49$ & $27.6^{\mathrm{B}} \pm 0.55$ \\
$\mathrm{C}+$ & $23.8^{\mathrm{A}} \pm 0.79$ & $25.3^{\mathrm{A}} \pm 0.44$ & $27.4^{\mathrm{B}} \pm 0.58$ \\
\hline
\end{tabular}

${ }_{\mathrm{A}, \mathrm{B}}$ Superscripts with different capital letters in the same column indicate very significant differences $(\mathrm{P}<0,05)$. $\mathrm{C}$ - $=0 \mathrm{mg}$ fraction $/ \mathrm{kg}$ bodyweight; $\mathrm{C}+=$ Glibenclamide $3 \mathrm{mg} / \mathrm{kg}$ bodyweight; $\mathrm{T} 1$ = extract $175 \mathrm{mg} / \mathrm{kg}$ bodyweight; T2 = extract $350 \mathrm{mg} / \mathrm{kg}$ bodyweight; T3 = extract $700 \mathrm{mg} / \mathrm{kg}$ bodyweight; SEM= Standar Error of Mean.

chemical compounds that are thought to have the working effect of flavonoids, alkaloids, tannins, saponins, and phenols.

Flavonoids play a role in pancreatic tissue damage caused by DNA alkylation due to alloxan induction as a result of improving the morphology of the rat pancreas. ${ }^{8,17}$ Flavonoids have antihyperglycemic activity because they act as antioxidants and aldose reductase inhibitors. The free radical quenching ability is an important link to prevent the oxidative stress related to hyperglycemia. The enzyme inhibitory activity was not linearly correlated to TPC of the extracts; however, it was associated with individual type of phenolic compound. ${ }^{31}$

Moroever, flavonoids can reduce blood sugar levels by inhibiting intestinal mucosa GLUT2 resulted in reduction in the absorption of glucose from the intestines. Another mechanism of flavonoids that shows a hypoglycemic effect is to reduce glucose uptake and regulate the activity of enzyme expression involved in carbohydrate metabolism. ${ }^{30}$

Saponin compounds contained in herbal plants can act by stimulating insulin in the pancreas and increasing insulin activity.
The decrease in glucose levels is due to the presence of beta cells which maintain the balance of homeostasis results in smoothness release of insulin. Whereas, tannins increase glucose absorption and inhibit adipogenesis. They also acts as a chelating agent that can constrict the epithelial membrane of the small intestine, thereby reducing the absorption of food juices and consequently inhibiting sugar intake and the rate of increasing blood sugar is not too high. ${ }^{20}$

The diabetic mice experience weight loss due to in diabetic conditions, the existing glucose cannot be used as an energy source and the fat and protein in muscle tissue and adipose will be catabolized excessively. The loss of glucose with urine in diabetics will lead to reduced use of glucose as an energy source, where the patient will experience a negative calorie balance, because every gram of glucose excreted causes the body to lose four calories, as a result the hypothalamic appetite center will aroused to meet the energy of the body, fat and protein in muscle tissue and adipose are catabolized excessively, resulting in weight loss. The results of bodyweight are shown in Table 5, the diabetic mice possess weight loss (C-) and significant reduced of body weight compared to the treatment group. It seems due to in diabetic conditions, 
Table 6. Daily Drinking Water Consumption

\begin{tabular}{cccccc}
\hline Day Treat- & \multicolumn{5}{c}{ The Average Daily Drinking Water Consumption (mL) \pm SEM (Days) } \\
\cline { 2 - 6 } ment Group & Day 0 & Day 7 & Day 10 & Day 14 & Day 18 \\
\hline $\mathrm{C}-$ & $0.81^{\mathrm{A}} \pm 0.12$ & $2.26^{\mathrm{A}} \pm 0.15$ & $2.46^{\mathrm{A}} \pm 0.16$ & $3.33^{\mathrm{B}} \pm 0.27$ & $3.46^{\mathrm{B}} \pm 0.14$ \\
$\mathrm{~T} 1$ & $0.95^{\mathrm{A}} \pm 0.20$ & $2.38^{\mathrm{A}} \pm 0.17$ & $2.51^{\mathrm{A}} \pm 0.30$ & $2.44^{\mathrm{A}} \pm 0.15$ & $1.50^{\mathrm{A}} \pm 0.17$ \\
$\mathrm{~T} 2$ & $0.83^{\mathrm{A}} \pm 0.11$ & $2.48^{\mathrm{A}} \pm 0.16$ & $2.50^{\mathrm{A}} \pm 0.31$ & $2.43^{\mathrm{A}} \pm 0.18$ & $1.71^{\mathrm{A}} \pm 0.20$ \\
$\mathrm{~T} 3$ & $0.66^{\mathrm{A}} \pm 0.06$ & $2.63^{\mathrm{A}} \pm 0.19$ & $2.10^{\mathrm{A}} \pm 0.24$ & $1.98^{\mathrm{A}} \pm 0.16$ & $1.51^{\mathrm{A}} \pm 0.12$ \\
$\mathrm{C}+$ & $0.86^{\mathrm{A}} \pm 0.11$ & $2.58^{\mathrm{A}} \pm 0.13$ & $2.58^{\mathrm{A}} \pm 0.16$ & $2.36^{\mathrm{A}} \pm 0.21$ & $1.60^{\mathrm{A}} \pm 0.10$ \\
\hline
\end{tabular}

$\mathrm{A}, \mathrm{B}$ Superscripts with different capital letters in the same column indicate very significant differences $(\mathrm{P}<0,05)$. $\mathrm{C}-=0 \mathrm{mg}$ fraction $/ \mathrm{kg}$ bodyweight; $\mathrm{C}+=$ Glibenclamide $3 \mathrm{mg} / \mathrm{kg}$ bodyweight; $\mathrm{T} 1=$ extract $175 \mathrm{mg} / \mathrm{kg}$ bodyweight; T2 = extract $350 \mathrm{mg} / \mathrm{kg}$ bodyweight; T3 = extract $700 \mathrm{mg} / \mathrm{kg}$ bodyweight; SEM= Standar Error of Mean.

the existing glucose cannot be used as an energy source, so to meet energy needs, fat and protein in both muscle and adipose tissue will be catabolized excessively and cause a decrease in body weight in diabetic mice but not in other mice $\left(\mathrm{C}+, \mathrm{T} 1, \mathrm{~T} 2\right.$, and T3). ${ }^{4,5}$

Diabetic mice can experience an increase in drinking water consumption, this happens because in DM, excessive sugar levels cannot be processed into energy due to lack of insulin so that the sugar will be excreted with urine. Sugar that attracts water will remove water and fluids in the blood will also be drawn out which causes the body to lack fluids so that the body will tried to return fluids by causing thirst. The high consumption of drinking water in mice can affect the volume of urine produced. The average volume of drinking water is presented in Table 6 .

The extract administration reduced the reconsumption of drinking water from diabetic mice. Increasing glucose levels causes the dehydration of tissue cells because glucose is hardly diffuse through the pores of the cell membrane, and the increased of osmotic pressure in the extracellular fluid causes an osmotic displacement of water out of the cell. To replace this, body will become thirsty and drink water in large volumes, results in the increase of water consumption. In addition, physiological and environmental factors can also affect the daily drinking water consumption.

\section{Mice Urine Volume}

The volume of urine in mice is closely related to the daily drinking water consumption of the mice and their blood sugar levels. The higher blood sugar will cause the body to excrete it with urine, causing increased urine volume (polyuria). The mean daily urine of (24 hours) mice is presented in Table 7.,8,9

Based on the results, it can be stated that the provision of sungkai leaf extract can reduce the urine volume (polyuria) of diabetic mice. On the other hand, like drinking water consumption for mice, the urine volume of mice can also be influenced by physiological and environmental factors so that it can affect the results of the study. The amount of glucose entering the renal tubule in the glomerular filtrate increases to a high level, causing the filtered glucose load to exceed its maximum transport and as a result the excretion of glucose in the urine. The results in an increase in the volume of urine formed as well as an increase in the excretion of other electrolytes. The increase in urine output is caused by a more active kidney, if the glucose 
Table 7. Average Daily Urine Volume

\begin{tabular}{cccccc}
\hline Treatment & \multicolumn{4}{c}{ The Average Daily Drinking Water Consumption (mL) \pm SEM (days) } \\
\cline { 2 - 6 } Group & Day 0 & Day 7 & Day 10 & Day 14 & Day 18 \\
\hline C- & $0.81^{\mathrm{A}} \pm 0.14$ & $4.11^{\mathrm{A}} \pm 0.32$ & $3.47^{\mathrm{A}} \pm 0.34$ & $4.10^{\mathrm{B}} \pm 0.29$ & $3.98^{\mathrm{B}} \pm 0.14$ \\
$\mathrm{~T} 1$ & $0.83^{\mathrm{A}} \pm 0.18$ & $1.96^{\mathrm{A}} \pm 0.27$ & $3.02^{\mathrm{A}} \pm 0.41$ & $1.96^{\mathrm{A}} \pm 0.20$ & $1.11^{\mathrm{A}} \pm 0.17$ \\
$\mathrm{~T} 2$ & $0.88^{\mathrm{A}} \pm 0.08$ & $2.38^{\mathrm{A}} \pm 0.33$ & $3.06^{\mathrm{A}} \pm 0.35$ & $2.38^{\mathrm{A}} \pm 0.25$ & $1.53^{\mathrm{A}} \pm 0.20$ \\
$\mathrm{~T} 3$ & $0.70^{\mathrm{A}} \pm 0.11$ & $2.14^{\mathrm{A}} \pm 0.47$ & $3.03^{\mathrm{A}} \pm 0.24$ & $2.10^{\mathrm{A}} \pm 0.23$ & $1.20^{\mathrm{A}} \pm 0.12$ \\
$\mathrm{C}+$ & $0.84^{\mathrm{A}} \pm 0.12$ & $2.66^{\mathrm{A}} \pm 0.27$ & $3.75^{\mathrm{A}} \pm 0.24$ & $2.66^{\mathrm{A}} \pm 0.12$ & $1.42^{\mathrm{A}} \pm 0.10$ \\
\hline
\end{tabular}

A,B Superscripts with different capital letters in the same column indicate very significant differences $(\mathrm{P}<0,05)$.

$\mathrm{C}$ - $=0 \mathrm{mg}$ fraction $/ \mathrm{kg}$ bodyweight; $\mathrm{C}+=$ Glibenclamide $3 \mathrm{mg} / \mathrm{kg}$ bodyweight; $\mathrm{T} 1$ = extract $175 \mathrm{mg} / \mathrm{kg}$ bodyweight; T2 = extract $350 \mathrm{mg} / \mathrm{kg}$ bodyweight; T3 = extract $700 \mathrm{mg} / \mathrm{kg}$ bodyweight; SEM= Standar Error of Mean.

level in the blood is high, the kidneys will excrete excess glucose through urine so that mice with diabetes will excrete a lot of urine.

\section{Conclusion}

The ethanol extract of sungkai leaves ( $P$. canescens Jack) contains several secondary metabolite compounds, phenol, flavonoids, tannins, alkaloids, and saponins that might play a role in reducing blood sugar levels of diabetic mice following reducing urine volume, daily drinking, and body weight in diabetic mice. In this study, it was known that a dose of $350 \mathrm{mg} / \mathrm{kg}$ of bodyweight provides the most effective activity as an antidiabetic.

\section{Acknowledgement}

\section{Funding}

This research was funded by DIPA PNBP, Faculty of Science and Technology, UNJA Basic Research, 2020. Number: SPDIPA-023.17.2.677565/2020.

\section{Conflict of Interest}

None declared

\section{References}

1. Akash MSH, Rehman K, Chen S. Role of inflammatorymechanisms in pathogenesis of type 2 diabetes mellitus. Journal Cell Biochemistry. 2013;114(3):525-531. doi:10.1002/jcb.24402

2. Akash MSH, Shen Q, Rehman K, Chen S. Interleukin-1 Receptor Antagonist: A New Therapy for Type 2 Diabetes Mellitus. Journal Pharmacy Sciences. 2012;101(7):2271-2280. doi:10.1002/jps

3. Rizvi SI, Mishra N. Traditional Indian Medicines Used for the Management of Diabetes Mellitus. Journal of Diabetes Research. 2013;2013:1-31.

4. Nasser Singab A, Youssef FS, Ashour ML. Medicinal Plants with Potential Antidiabetic Activity and their Assessment. Medicinal and Aromatic Plants. 2014;03(01):1-12.

5. International Diabetes Federation. Diabetes Atlas. Sixth Edition. Brussels, Belgium: International Diabetes Federation; 2014.

6. Rudijanto A, Saraswati MR, Yunir E, Kumala P, Puteri HH, Mandang VV. Indonesia Cohort of IO HAT Study to Evaluate Diabetes Management, Control, and Complications in Retrospective and Prospective Periods Among InsulinTreated Patients with Type 1 and Type 2 Diabetes. Acta Medica Indonesiana. 2018;50(1):26-37.

7. Soewondo P, Ferrario A, Tahapary DL. 
Challenges in diabetes management in Indonesia: A literature review. Global Health. 2013;9(1).

8. Adnyana IDPA, Meles DK, Wurlina, Zakaria S, Suwasanti N. Efek Anti Diabetes Buah Pare (Momordica charantia Linn.) Terhadap Kadar Glukosa Darah, Sel Penyusun Pulau Langerhans dan Sel Leydig pada Tikus Putih Hiperglikemia. Acta Veterinaria Indonesiana. 2017;4(2):43-50.

9. Madelina W, Untari EK, Nansy E. Efek Perseptif Penggunaan Kombinasi Antidiabetes Oral-Insulin pada Pasien Diabetes Melitus Tipe 2 di Kota Pontianak dan Sekitarnya. Indonesian Journal of Clinical Pharmacy. 2018;7(3):209.

10. Putra RJS, Achmad A, Rachma P H. Kejadian Efek Samping Potensial Terapi Obat Anti Diabetes Pada Pasien Diabetes Melitus Berdasarkan Algoritme Naranjo. Pharmacy Journal Indonesia. 2017;2(2):45-50. https://pji.ub.ac.id/ index.php/pji/article/view/49/23

11. Jalius, Muswita. Eksplorasi Pengetahuan Lokal tentang Tumbuhan Obat di Suku Batin, Jambi. Biospecies. 2013;6(1):2836.

12. Kusriani RH, Nawawi A, Taufik T. Uji Aktivitas Antibakteri Ekstrak dan Fraksi Kulit Batang dan Daun Sungkai (Peronema canescens Jack). Jurnal Farmasi Galenika. 2015;02(01):8-14.

13. Ramadenti F, Sundaryono A, Handayani D. Uji Fraksi Etil Asetat Daun Peronema canescens terhadap Plasmodium berghei pada Mus musculus Fuji. Alotrop. 2017;1(2):89-92.

14. Ibrahim A, Kuncoro H. Identifikasi Metabolit Sekunder dan Aktivitas Antibakteri Ekstrak Daun Sungkai (Peronema canescens JACK.) Terhadap Beberapa Bakteri Patogen. Journal of Tropical Pharmacy and Chemistry. 2012;2(1):8-18.
15. Putranto AMH. Examination of the Sungkai's Young Leaf Extract (Peronema canescens) as an Antipiretic, Immunity, Antiplasmodium, and Teratogenity in Mice (Mus musculus). International Journal of Science and Engineering. 2014;7(1):30-34.

16. Marianne, Yuandani, Rosnani. AntidiabeticActivityFromEthanolExtract of Kluwih's Leaf (Artocarpus camansi). Jurnal Natural. 2011;11(2):115070.

17. Abdelmoaty MA, Ibrahim MA, Ahmed NS, Abdelaziz MA. Confirmatory studies on the antioxidant and antidiabetic effect of quercetin in rats. Indian Journal of Clinical Biochemistry. 2010;25(2):188192.

18. Beecher GR. Proanthocyanidins: Biological activities associated with human health. Pharmaceutical Biology. 2004;42(SUPPL.):2-20.

19. Gülçin I, Huyut Z, Elmastaș M, AboulEnein HY. Radical scavenging and antioxidant activity of tannic acid. Arabian Journal of Chemistry. 2010;3(1):43-53. doi:10.1016/j.arabjc.2009.12.008

20. Amiraragab B, Hussein SA, Alm-Eldeen A-E, Hafe z A, Mohamed T. Saponins and their potential role in diabetes mellitus. Diabetes Management. 2017;7(1):148158.

21. Tarigan IL, Sari AK, Huda C, Jovanncha C, Muadifah A. Phytochemical Screening and Quantitative Analysis of Coleus arthropurpureus Ethyl Acetate Fraction and Antibacterial Activity Agains Staphylococcus aureus. ALKIMIA Jurnal Ilmu Kimia dan Terapan. 2020;4(1):1723. doi:10.19109/alkimia.v4i1.5123

22. Anwar K, Putri ANL, Eka RHP, Kamalia N, Santoso HB. Perbandingan Efek Ekstrak Etanol, Fraksi N- Butanol , dan Fraksi Petroleum Eter Daun Kembang Bulan (Tithonia diversifolia (Hemsley) A Gray) Terhadap Penurunan 
Kadar Glukosa Darah Mencit Jantan Yang Diinduksi Aloksan. Jurnal Pharmascience. 2016;03(02):80-88.

23. Departemen Kesehatan Republik Indonesia. Informatorium Obat Nasional Indonesia. Departemen Kesehatan Republik Indonesia; 2000.

24. Departemen Kesehatan Republik Indonesia. Farmakope Herbal Indonesia. Departemen Kesehatan Republik Indonesia; 2008.

25. Latief M, Nelson N, Amanda H, Tarigan IL, Aisyah S. Potential Tracking of Cytotoxic Activities of Mangrove Perepate (Sonneratia alba) Root Extract as an Anti-Cancer Candidate. Pharmacology and Clinical Pharmacy Research. 2020;5(2):48-55.

26. Firdous M, Koneri R, Sarvaraidu CH, Shubhapriya KH. NIDDM Antidiabetic Activity of Saponins of Momordica Cymbalaria In StreptozotocinNicotinamide NIDDM Mice. Journal of Clinical and Diagnostic Research. 2009;3(October 2008):1460-1465.

27. Chaudhury A, Duvoor C, Reddy Dendi VS, et al. Clinical Review of Antidiabetic Drugs: Implications for Type 2 Diabetes Mellitus Management. Front Endocrinol (Lausanne). 2017;8(January). doi:10.3389/fendo.2017.00006

28. Shiyan S, Herlina H, Arsela D, Latifa E. Aktivitas Antidiabetes Ekstrak Etanolik Daun Kopi Robustra (Coffea canephora) Pada Tikus Diabetes Tipe 2 yang diberi Diet Lemak Tinggi dan Sukrosa. Jurnal Farm Sains dan Praktis. 2017;3(2):39-46. doi:10.31603/pharmacy.v3i2.1730

29. Yunus Y, Zubaidah E. The Effect of Sucrose Concentration and Fermentation Time to Viability of Lactobacillus casei during Frozen Storage for Velva from Ambon Banana. Jurnal Pangan dan Agroindustri. 2015;3(2):303-312.

30. Brahmachari G. Bio-flavonoids with promising anti- diabetic potentials : A critical survey. Opportunity, Challenge and Scope of Natural Products in Medicinal Chemistry. 2011;661(2):187212.

31. Sekhon-Loodu S and Rupasinghe HPV (2019) Evaluation of Antioxidant, Antidiabetic and Antiobesity Potential of Selected Traditional Medicinal Plants. Frontiers in Nutrition. 6:53. 